\title{
HEAVY METAL AND ANTIBIOTIC RESISTANCE BACTERIA IN MARINE SEDIMENT OF PAHANG COASTAL WATER
}

\author{
Zaima Azira Zainal Abidin" ${ }^{*}$, Ahmed Jalal Khan Chowdhury² \\ 1 Department of Biotechnology, Kulliyyah of Science, International Islamic University Malaysia 25200, Kuantan, Pahang, Malaysia \\ 2 Department of Marine Science, Kulliyyah of Science, International Islamic University Malaysia 25200, Kuantan, Pahang, Malaysia \\ *Corresponding author email: zzaima@iium.edu.my
}

\section{ARTICLE DETAILS}

\section{Article History:}

Received 12 November 2017 Accepted 12 December 2017 Available online 1 January 2018

\section{Keywords:}

antibiotic, Chromium, Cadmium, Nickel, Copper, Cobalt

\section{ABSTRACT}

The presence of heavy metal and antibiotic resistance bacteria in the marine sediment may indicate heavy metal pollution and antibiotic abuse present in the environment. In this study, a total of 89 bacteria isolated from sediment collected in Teluk Chempedak and Pantai Batu Hitam of Pahang coastal water underwent heavy metal resistance test against Chromium, Cadmium, Nickel, Copper and Cobalt. Previously, these isolates were found to exhibit antibiotic resistance capabilities to at least 5 antibiotics tested. Heavy metal resistance pattern for isolates from Teluk Chempedak was in the form of $\mathrm{Cr}>\mathrm{Ni}>\mathrm{Co}>\mathrm{Cd}=\mathrm{Cu}$ while for isolates from Pantai Batu Hitam showed a pattern of $\mathrm{Cr}$ $=\mathrm{Ni}>\mathrm{Co}>\mathrm{Cu}>\mathrm{Cd}$. Further investigation on the identity of selected isolates that exhibited both antibiotic and heavy metals resistance capabilities using 16S rRNA gene sequences revealed isolates with closest similarities to Staphylococcus saprophyticus and Brevundimonas vesicularis..

\section{INTRODUCTION}

Extremely dangerous and toxic heavy metals can disrupt ecological activities in the aquatic environment and exposure of excessive heavy metals may cause contaminated sediments [1]. Heavy metals can lead to degradation of marine ecosystems by decreasing species variety over accretion of metals in living animals and food chains [2]. Moreover, human activities also contributed to the deposition of heavy metals in the environment the condition is worsened by accumulation through food sources and finally lead to serious health and ecological problems [3]. Heavy metals can be discharged into the marine environment through many ways such as industries, wastewaters, and domestic effluents [4]. The effects of heavy metal into the environment however, will depend on its concentration and accessibility of metals.

Heavy metals ( $\mathrm{Fe}, \mathrm{Zn}, \mathrm{Mn}, \mathrm{Co}, \mathrm{Cu}, \mathrm{Ni}, \mathrm{V}, \mathrm{Mo}$ ) are essential micronutrients for bacteria because they are incorporated into enzymes and cofactors. However, high concentrations of these heavy metals are toxic due to binding of the metals to enzymes and DNA and also the production of oxygen radicals through Fenton reactions [5]. Microbial metal resistance mechanisms include the precipitation of metals as phosphates, carbonates and sulphides; metal volatilization through methyl or ethyl group addition; physical exclusion by electronegative components in membranes and exopolymers; energy-dependent metal efflux systems; and intracellular sequestration with low molecular weight, cysteine-rich proteins [6].

Reports on the incidence of antibiotic and heavy metal resistance bacteria in aquatic environments were found to be increasing worldwide annually [7-10]. Such reports are alarming because they indicate potential risk and threats to the marine ecosystem as well to the human health. This study focused on two locations Teluk Chempedak and Pantai Batu Hitam, both of which are popular as tourist attraction in Pahang. This study aimed to assess the antibiotic and heavy metal resistance bacteria present in the marine sediment associated with both locations.

\section{MATERIALS AND METHODS}

\subsection{Bacterial Isolates}

In total 89 bacterial isolates from marine sediment collected at Teluk Chempedak (N 03' 48.650 E 103' 22.573) and Pantai Batu Hitam (N 03 53.115 E 103 ' 22.283) were used in this study. Previously, antibiotic susceptibility test was conducted on all isolates against 10 antibiotics vancomycin, tetracycline, streptomycin, penicillin G, ampicillin, rifampicin, polymyxin, chloramphenicol, erythromycin and gentamicin [11].

\subsection{Determination of the minimal inhibitory concentration (MIC) of heavy metals}

The heavy metal resistance of the strains was determined using MuellerHinton agar (MHA) supplemented with various concentrations of five different heavy metals $\left(\mathrm{Cd}^{2+}, \mathrm{Cu}^{2+}, \mathrm{Cu}^{2+}, \mathrm{Co}^{2+}, \mathrm{Ni}^{2+}\right)$ in the form of chloride salts. Initial concentration of the heavy metal was at $20 \mu \mathrm{g} / \mathrm{ml}$ and the concentration of the heavy metals was gradually increased at $10 \mu \mathrm{g} / \mathrm{ml}$ until the isolates failed to grow.

\subsection{Identification of isolates using $16 \mathrm{~S}$ rRNA gene sequence}

PCR amplification of 16S rRNA gene were done using the following set of primers: 27F 5'-AGAGTTTGATCCTGGCTCTCAG-3' and 1492R 5'GGTTACCTTGTTACGACTT-3'. The PCR reactions were performed in a final volume of $50 \mu \mathrm{l}$ which consist of $200 \mathrm{ng}$ DNA template, $25 \mu \mathrm{l}$ of MyTaq $^{\text {TM }}$ Mix 2X (Bioline, UK) and $0.4 \mu \mathrm{M}$ primers under the following conditions: initial denaturation at $94^{\circ} \mathrm{C}$ for $5 \mathrm{~min}$, followed by 30 cycles of $94{ }^{\circ} \mathrm{C}$ for $30 \mathrm{~s}, 55^{\circ} \mathrm{C}$ for $60 \mathrm{~s}$ and $72{ }^{\circ} \mathrm{C}$ for $4 \mathrm{~min}$; and extension step at 72 ${ }^{0} \mathrm{C}$ for $10 \mathrm{~min}$. The amplification products were confirmed using $1 \%$ agarose gel and sent to $1^{\text {st }}$ Base Laboratory, Malaysia for purification and sequencing. The resultant $16 \mathrm{~S}$ rRNA gene sequences were manually verified and edited using BioEdit Sequence Alignment Editor. The partial nucleotide sequences analyses of the isolates were carried out via GenBank BLASTn (http://www.ncbi.mlm.nih.gov) search tool.

\section{RESULTS AND DISCUSSION}

The susceptibility to five heavy metals $\left(\mathrm{Cd}^{+2}, \mathrm{Cr}^{+3}, \mathrm{Cu}^{+2}, \mathrm{Co}^{+2}\right.$ and $\left.\mathrm{Ni}^{+2}\right)$ at a range of concentrations was recorded for all isolates for both locations as in Table 1 and Table 2. Isolates from Pantai Batu Hitam showed a higher resistance to chromium, nickel and cobalt whereas isolates from Teluk Chempedak showed a higher resistance to chromium in particular. Teluk 
Chempedak isolates were found to be more susceptible to cadmium and copper at MIC range of $50-100 \mu \mathrm{g} / \mathrm{ml}$. Interestingly, almost all isolates from Pantai Batu Hitam displayed high resistance to both chromium and nickel with MIC $>500 \mu \mathrm{g} / \mathrm{ml}$ and half of the isolates showed high resistance to both copper and cobalt with similar MIC. The resistance pattern associated with Teluk Chempedak and Pantai Batu Hitam were $\mathrm{Cr}$ $>\mathrm{Ni}>\mathrm{Co}>\mathrm{Cd}=\mathrm{Cu}$ and $\mathrm{Cr}=\mathrm{Ni}>\mathrm{Co}>\mathrm{Cu}>\mathrm{Cd}$ respectively.

Table 3 depicts selected isolates from both location that exhibited both antibiotic and heavy metal resistance capabilities. Isolate TC 46 was resistant to 8 antibiotics and resistant to chromium, cadmium and cobalt with MIC range of $350-400 \mu \mathrm{g} / \mathrm{ml}$ while TC 48 was resistant to 7 antibiotics and resistant to chromium, cadmium and cobalt with MIC of $450 \mu \mathrm{g} / \mathrm{ml}$. TC50, however, was resistant to 7 antibiotics and resistant to chromium and cadmium with MIC $>500 \mu \mathrm{g} / \mathrm{ml}$ and MIC for cobalt of 450 $\mu \mathrm{g} / \mathrm{ml}$. Isolates BH 45 and BH 50 were resistant to 7 antibiotics and all were highly resistant to chromium, nickel, copper and cobalt with MIC > $450 \mu \mathrm{g} / \mathrm{ml}$. Similar results was also obtained on isolate 6 that was resistant to 8 antibiotics. The genes encoding resistance to heavy metals can be located together with antibiotic resistance genes on either the same genetic structure or different genetic structures within the same bacterial strain Metal and antibiotic resistances are the most common features that bacteria gain due to the abuse of metals and/or antibiotic [12]. Recent studies have suggested that the presence of metal contamination in natural environments could play a role in the maintenance and proliferation of antibiotic resistance [13,14].

The 16S rRNA gene sequence analysis of isolate TC 50 revealed that it has the closest relationship to Staphylococcus saprophyticus ATC $15305(100$ $\%$ ), while isolate $\mathrm{BH} 50$ possess the closest relationship with $99 \%$ similarity to Brevundimonas vesicularis IAM 12105. S. saprophyticus is a gram-positive coccus commonly found in urine specimen and a common cause of urinary tract infection. Reports on multiple antibiotic resistant $S$. saprophyticus were mostly related to clinical isolates from hospitals but none from the marine environment [15]. High number of tourists in Teluk Chempedak might implicate to high volume of waste water (excrete products, urine) discharged into the marine environment and which eventually led to its residing in the marine sediment. Additionally, there was no report on S. saprophyticus to possess both antibiotic and heavy metal resistant capabilities. Hence, this is the the first report of such incidence. Meanwhile, B. vesicularis can be isolated from the human end cervix, natural soil environments, bottled water and hospital environments [16]. This bacterium can cause arthritis, endocarditis, meningitis and primary bloodstream infection in immunocompromised as well as immunocompetent patient [17]. Similar to S. saprophyticus, reports on $B$. vesicularis were mostly on its multiple antibiotic resistance ability but none on the heavy metal resistant ability. Hence, this is the the first report of such incidence for both $S$. saprophyticus and B. vesicularis. Results obtained in this study indicated the possibility of marine environments of Teluk Chempedak and Pantai Batu Hitam were of poor microbiological quality which has led to bacterial isolates to gain resistance against several antibiotic agents and together with high numbers of heavy metal resistant bacteria could be the result of agrochemical and industrial pollution.

Table 1: Heavy metal tolerance in bacteria from marine sediment of Teluk Chempedak

\begin{tabular}{|c|c|c|c|c|c|c|c|}
\hline \multirow{2}{*}{$\begin{array}{l}\text { Heavy } \\
\text { Metal }\end{array}$} & \multicolumn{7}{|c|}{ MIC $(\mu \mathrm{g} / \mathrm{ml})$ with number of tolerant isolates } \\
\hline & $<\mathbf{5 0}$ & $\begin{array}{l}50- \\
100\end{array}$ & $\begin{array}{l}110- \\
200\end{array}$ & $\begin{array}{l}210- \\
300\end{array}$ & $\begin{array}{l}310- \\
400\end{array}$ & $\begin{array}{l}410- \\
500\end{array}$ & $>500$ \\
\hline Cd & & 45 & 5 & & & & \\
\hline Co & & 11 & 29 & & 5 & 5 & \\
\hline $\mathrm{Cr}$ & & & & 14 & 15 & 13 & 8 \\
\hline $\mathrm{Cu}$ & & 45 & 5 & & & & \\
\hline $\mathbf{N i}$ & 10 & & 17 & 16 & 2 & 3 & 2 \\
\hline
\end{tabular}

Table 2: Heavy metal tolerance in bacteria from marine sediment of Pantai Batu Hitam

\begin{tabular}{|c|c|c|c|c|c|c|c|}
\hline \multirow{2}{*}{$\begin{array}{l}\text { Heavy } \\
\text { Metal }\end{array}$} & \multicolumn{7}{|c|}{ MIC $(\mu \mathrm{g} / \mathrm{ml})$ with number of tolerant isolates } \\
\hline & $<50$ & $\begin{array}{l}50- \\
100\end{array}$ & $\begin{array}{l}110- \\
200\end{array}$ & $\begin{array}{l}210- \\
300\end{array}$ & $\begin{array}{l}310- \\
400\end{array}$ & $\begin{array}{l}410- \\
500\end{array}$ & $>500$ \\
\hline Cd & & 7 & 32 & & & & \\
\hline Co & & 2 & 2 & 1 & 9 & 7 & 18 \\
\hline $\mathrm{Cr}$ & & 1 & & & & & 38 \\
\hline $\mathrm{Cu}$ & & 18 & & 6 & & & 15 \\
\hline $\mathbf{N i}$ & & 1 & & & & & 38 \\
\hline
\end{tabular}

Table 3: Selected antibiotic and heavy metals resistance isolates from Teluk Chempedak (TC) and Pantai Batu Hitam (BH)

\begin{tabular}{cll}
\hline Isolates & \multicolumn{1}{c}{ Antibiotic } & \multicolumn{1}{c}{ Heavy Metal } \\
\hline TC 46 & $\begin{array}{l}\text { Vancomycin, Ampicillin, Tetracycline, Chloramphenicol, } \\
\text { Penicillin G, Streptomycin, Gentamycin, Rifampicin }\end{array}$ & $\begin{array}{l}\text { Chromium, } \\
\text { Cadmium, Cobalt }\end{array}$ \\
\hline \multirow{2}{*}{ TC 48 } & $\begin{array}{l}\text { Vancomycin, Ampicillin, Tetracycline, Chloramphenicol, } \\
\text { Gentamycin, Rifampicin, Penicillin G }\end{array}$ & $\begin{array}{l}\text { Chromium, } \\
\text { Cadmium, Cobalt }\end{array}$ \\
\hline \multirow{2}{*}{ TC 50 } & $\begin{array}{l}\text { Vancomycin, Ampicillin, Tetracycline, Chloramphenicol, } \\
\text { Gentamycin, Rifampicin, Penicillin G }\end{array}$ & $\begin{array}{l}\text { Chromium, } \\
\text { Cadmium, Cobalt }\end{array}$ \\
\hline \multirow{2}{*}{ BH 6 } & Vancomycin, Ampicillin, Tetracycline, Chloramphenicol, \\
& Penicillin G, Streptomycin, Gentamycin, Rifampicin & $\begin{array}{l}\text { Chromium, Copper, } \\
\text { Cobalt, Nickel }\end{array}$ \\
\hline BH 45 & $\begin{array}{l}\text { Vancomycin, Tetracycline, Chloramphenicol, } \\
\text { Erythromycin, Streptomycin, Gentamycin, Rifampicin }\end{array}$ & $\begin{array}{l}\text { Chromium, Copper, } \\
\text { Cobalt, Nickel }\end{array}$ \\
\hline \multirow{2}{*}{ BH 50 } & $\begin{array}{l}\text { Vancomycin, Tetracycline, Chloramphenicol, }, \\
\text { Erythromycin, Streptomycin, Gentamycin, Rifampicin }\end{array}$ & $\begin{array}{l}\text { Chromium, Copper, } \\
\text { Cobalt, Nickel }\end{array}$ \\
\hline
\end{tabular}

\section{CONCLUSION}

In conclusion, the occurrence of antibiotic and heavy metal resistant bacteria in Pahang coastal water indicated the impact of human activities on the marine environment which constituting a risk to the public health and pose a threat to the marine ecosystem. In addition, marine sediment in both locations probably represents a reservoir of multiresistant genetic elements which bacteria can attain through horizontal gene transfer.

\section{ACKNOWLEDGEMENT}

This work was supported by RAGS12-036-0036 funded by Ministry of Higher Education (MOHE) of Malaysia

\section{REFERENCES}

[1] Yamina, B.T. 2012. Isolation and screening of heavy metal resistance bacteria from wastewater: A study of heavy metal co-resistance and antibiotic resistance. Water Science and Technology. A Journal of the International Association on Water Pollution Research, 66 (10), 20412048.

[2] Hosono, T., Su, C.C., Siringan, F., Amano, A., Onodera, S.I. 2011 Effects of environmental regulation on heavy metal pollution decline in core sediments from Manila Bay. Marine Pollution Bulletin, 60 (5), 780785 .

[3] Mondragón, V.A., Llamas-Pérez, D.F., González-Guzmán, G.E. Márquez-González, A.R., Padilla-Noriega, R., Durán-Avelar, M.J., Franco, B. 2011. Identification of Enterococcus faecalis bacteria resistant to heavy metals and antibiotics in surface water of Mololoa River in Tepic, Nayarit, Mexico. Environmental Monitoring and Assessment, 183 (1-4), 329-340.

[4] Fu, F.W., Qi, W. 2011. Removal of heavy metal ion from wastewaters: A review. Journal of Environmental Management, 92 (3), 407-408.

[5] Lopez-Maury, L., Garcia-Dominguez, M., Florencio, F.J., Reyes, J.C. 2002. A two-component signal transduction system involved in nickel sensing in the Cyanobacterium Synechocyystis sp. PCC 6803. Molecular Microbiology, 43 (1), 247-256. 
[6] Silver, S. 1998. Genes for all metals a bacterial view of the periodic table. J Ind Microbiol Biot, 20 (1), 1-12.

[7] Miranda, C.D., Castillo, G. 1998. Resistance to antibiotic and heavy metals of motile aeromonads from Chilean freshwater. Science of the Total Environment, 224 (1-3), 167-176.

[8] Matyar, F. 2007. Distribution and antimicrobial multiresistance in Gram negative bacteria isolated from Turkish sea bass (Dicentrarchus labrax L., 1781) farm. Annals of Microbiology, 57 (1), 35-38.

[9] Gul-Seker, M., Mater, Y. 2009. Assessment of metal and antibiotic resistance in marine bacteria isolated from Izmit Bay and Bosporus entrance of Marmara and Black Sea, Turkey. Fresenius Environmental Bulletin, 18, 2192-2202.

[10] Matyar, F. 2012. Antibiotic and heavy metal resistance in bacteria isolated from Mediterranean Sea coast. Bulletin of Environmental Contamination and Toxicology, 89 (3), 551-556.

[11] Rahman, N.A., Chowdhury, A.J.K., Abidin, Z.A.Z. 2015. Antibiotic resistant bacteria from sediment of coastal water of Pahang, Malaysia. Jurnal Teknologi, 77 (24), 65-70.

[12] Baker-Austin, C., Wright, M., Stephanauskas, R., McArthur, J.V. 2006.
Co-selection of antibiotic and metal resistance. Trends Microbiology, 14, (4), 176-182.

[13] Summers, A.O. 2002. Generally overlooked fundamentals of bacterial genetics and ecology. Clinical Infectious Diseases, 34 (3), 85-92.

[14] Matyar, F., Kaya, A., Dincer, S. 2008. Antibacterial agents and heavy metal resistance in Gram-negative bacteria isolated from seawater, shrimp and sediment in Iskenderun Bay, Turkey. Science of the Total Environment, 407 (1), 279-285.

[15] Sabzehali, F., Goudarzi, M., Goudarzi, H., Azimi, H. 2017. Distribution of Aminoglycoside Resistance Genes in Coagulase-Negative Staphylococci Isolated from Hospitalized Patients. Archives of Pediatric Infectious Diseases, 5 (3), e57297. doi: 10.5812/pedinfect. 57297

[16] Han, X.Y., Andrade, R.A. 2005. Brevundimonas diminuta infections and Its Resistance to Fluoroquinolones. Journal of Antimicrobial Chemotheraphy, 55 (6), 853-859.

[17] Zhang, C.C., Hsu, H.J., Li, C.M. 2012. Brevundimonas vesicularis Bacteremia Resistant to Trimethoprim-Sulfamethoxazole and Ceftazidime in a Tertiary Hospital in Southern Taiwan. Journal of Microbioloy, Immunology and Infection, 45 (6), 448-452 